\title{
FAKTOR - FAKTOR YANG MEMPENGARUHI IMPOR BERAS INDONESIA
}

\author{
Jumai Nizar ${ }^{\mathrm{a} *}$, Tarmizi Abbas ${ }^{\mathrm{a}^{*}}$ \\ ${ }^{a}$ Fakultas Ekonomi dan Bisnis Universitas Malikussaleh \\ * Corresponding author : jumainizar@gmail.com \\ * tarmiziabbas@unimal.ac.id
}

\section{ART I CLE INFORMATION}

Keywords:

Rice Imports, Inflation, Exchange Rates, Retail Prices, Multiple Linear

Regression, $A R D L$

\section{A B S T R A C T}

- This study aims to determine the factors that influence rice imports in Indonesia. The data used in this study are time series in the period 1999-2017. The analytical model used in this study is the Multiple Linear Regression Model and the ARDL Model. The results showed that are that together the Inflation, Exchange Rate and Retail Prices variables had a positive and significant effect on Rice Imports. While partially Inflation and retail prices each had a positive and significant effect on the Import of Rice. There is no influence exchange rate and negative effect on Rice Imports. From the results of the ARDL model it can be seen that the long-run and short-run inflation variables had no significant and negative effect on rice imports and the long-run exchange rate variable had a significant and negative effect on rice imports. While in the short run the exchange rate variable had no effect on rice imports, while the retail price variable in the short and long run had a significant and positive effect on rice imports in Indonesia.

\section{PENDAHULUAN}

Indonesia merupakan negara yang sebahagian besar penduduknya bermata pencaharian sebagai petani. Tidak hanya sebagai penopang perekonomian sebahagian masyarakat, sektor pertanian juga diandalkan sebagai penompang pembangunan negara.Salah satu komoditas pertanian yang dihasilkan ialah tanaman padi.

Padi merupakan bahan makanan yang menghasilkan beras. Sebagai kebutuhan bahan pangan masyarakat Indonesia padi di Indonesia tidak pernah surut baik dalam mengkonsusmsi maupun dalam memproduksi, melainkan kian bertambah dari tahun ke tahun sesuai dengan bertambahnya penduduk. Bahkan, Indonesia merupakan penghasil beras terbesar didunia dan berada pada urutan ketiga dari 10 negara yang menghasilkan beras terbesar didunia menurut FAO, dengan jumlah produksi hingga 75,6 juta ton.

Namun, kebutuhan beras sangat tinggi menyebabkan Indonesia masih harus mengimpor beras.Hal ini juga disebabkan karena jumlah penduduk yang semakin bertambah setiap tahunnya.Seiring bertambahnya jumlah penduduk setiap tahun maka lahan untuk pertanian juga semakin sempit, sehingga produksi padi akan

berkurang, sedangkan permintaan akan

beras di Indonesia sangat tinggi. Penurunan produksi beras juga akan berakibat pada kenaikan harga terhadap beras yang akhirnya akan terjadi penurunan akan permintaan beras dalam negeri. Berikut adalah data impor beras menurut negara asal pada tahun 2017.

\section{Tabel 1}

Data Impor Beras Menurut Negara Asal Tahun 2017

\begin{tabular}{|l|r|r|}
\hline $\begin{array}{c}\text { Negara } \\
\text { Asal }\end{array}$ & $\begin{array}{c}\text { Berat } \\
\text { Bersih/Ton }\end{array}$ & $\begin{array}{c}\text { Nilai CIF/000 } \\
\text { US\$ }\end{array}$ \\
\hline Vietnam & $16.599,9$ & $6.761,3$ \\
\hline Thailand & $108.944,8$ & $60.286,9$ \\
\hline India & $32.209,7$ & $13.397,1$ \\
\hline Pakistan & $87.500,0$ & $34.793,1$ \\
\hline $\begin{array}{l}\text { Tiongkok/ } \\
\text { China }\end{array}$ & $2.419,0$ & $8.118,7$ \\
\hline
\end{tabular}

Sumber: BPS, 2018

Impor beras Indonesia dari tahun ke tahun selalu terjadi peningkatan ini merupakan suatu kontroversi, dimana hasil produksi padi juga selalu meningkat di Indonesia.

Tujuan penelitian ini untuk mengetahui seberapa besarkah pengaruh inflasi, nilai tukar 
rupiah dan harga eceran terhadap impor beras Indonesia dan untuk mengetahui apakah hubungan jangka pendek dan jangka panjang dari inflasi, nilai tukar rupiah dan harga eceran berpengaruh terhadap impor beras Indonesia.

Selanjutnya pembahasan di bahagian kedua dalam artikel ini adalah landasan teoritis, di bahagian ketiga dibahas tentang metode penelitian. Pada bahagian keempat membahas hasil dan pembahasan dan akhirnya ditutup dengan kesimpulan dan saran pada bahagian kelima.

\section{LANDASAN TEORITIS}

\section{Impor}

Impor adalah kegiatan mengirimkan barang ke daerah pabean Indonesia. kegiatan impor di mulai dari adanya pelaku-pelaku yang terlibat, yaitu importir dan eksportir atas barang atau jasa tertentu dimana keduanya berada di kedua negara berbeda (Amir, 2001).

Keuntungan yang akan didapat melalui kegiatan impor yakni secara langsung akan membantu memenuhi ketersediaan barang-barang yang skala produksinya masih rendah. Membantu mengurangi meningkatnya harga jual yang di karenakan kurangnya stok, maupun menghindari kekurangan produk yang di butuhkan dalam negeri.

\section{Inflasi}

Inflasi adalah gejala ekonomi yang menunjukkan naiknya tingkat harga secara umum yang berkesinambungan. Syarat inflasi yaitu terjadi kenaikan harga-harga secara umum dan terus-menerus. Jika hanya satu atau dua jenis barang saja yang naik, itu bukan merupakan inflasi (Hasyim, 2016).

Paling tidak ada tiga teori tentang inflasi yang menjadi patokan penyebab dan pemberian solusi ketika terjadi inflasi. Ketiga teori tersebut diantaranya adalah teori kuantitas, teori keynes dan teori strukturalis.

Penelitian yang dilakukan oleh Saputra \& Swara (2014), bahwa inflasi tidak berpengaruh dan tidak signifikan terhadap impor gula Indonesia periode 2000-2012, yang artinya apabila inflasi meningkat maka impor juga meningkat. Hal ini juga sejalan dengan penelitian yang dilakukan oleh
(Wati \& Sudiana, 2013), menyatakan bahwa secara parsial inflasi tidak berpengaruh terhadap impor sayuran Indonesia tahun 1994-2013, artinya naik turunnya inflasi tidak mempengaruhi impor sayuran indonesia. inflasi dikatakan tidak berpengaruh signifikan terhadap impor sayuran Indonesia dikarenakan importir sayuran tidak memperhatikan presentase tingkat inflasi, jadi berapapun tingkat inflasi tidak akan mempengaruhi daya beli masyarakat indonesia.

\section{Nilai Tukar/ Kurs}

Kurs merupakan perbandingan nilai mata uang yang berbeda atau dikenal dengan sebutan kurs. Nilai tukar didasari dua konsep, pertama, konsep nominal dan kedua, konsep rill (Halwani, 2005).

Menurut Sukirno (2002), Kurs rupiah mempunyai hubungan terbalik dengan volume impor. Apabila nilai tukar rupiah mengalami peningkatan atau depresiasi, maka volume impor akan menurun.

Jadi, nilai tukar atau kurs merupakan suatu perbandingan mata uang suatu negara dengan negara lain.

Pada penelitian yang dilakukan oleh Singgih \& Sudirman, (2015), bahwa hasil yang didapatkan adalah secara parsial kurs Dollar AS tidak berpengaruh signifikan terhadap impor jagung Indonesia. Namun hal ini tidak sesuai dengan hasil penelitian yang dilakukan oleh (Prinadi, Yulianto, \& Mawardi, 2016), menyatakan bahwa hasil yang didapatkan adalah variabel kurs rupiah berpengaruh signifikan terhadap volume impor beras Indonesia, dimana apabila menguatnya nilai tukar rupiah terhadap US\$ maka akan membuat volume impor beras Indonesia meningkat.

\section{Harga Eceran}

Harga eceran adalah harga transaksi antara penjual dan pembeli untuk setiap jenis barang yang diecerkan menurut satuan setempat (Kamus Besar, 2019).

Dalam teori ekonomi disebutkan bahwa harga barang dan jasa yang pasarnya kompetetif, maka tinggi rendahnya harga ditentukan oleh permintaan dan penawaran pasar. 
Berdasarkan penelitian yang dilakukan oleh Saputra \& Swara, (2014), hasil analisis data menunjukkan secara Secara parsial harga eceran gula tidak berpengaruh signifikan terhadap impor gula Indonesia periode 2000-2012. Hal ini menggambarkan harga eceran gula yang semakin meningkat, dikarenakan harga gula dalam negeri tidak dapat bersaing dengan harga gula impor terkait dengan efektifitas produksi.

Penelitian yang dilakukan oleh (Prinadi et al., 2016), menunjukkan hasil yang berbeda yaitu secara parsial harga berpengaruh secara signifikan terhadap volume impor beras Indonesia, dengan kata lain meningkatnya harga membuat impor ikut mengalami peningkatan.

\section{Kerangka Pemikiran}

Berikut adalah kerangka pemikiran analisis faktor-faktor yang mempengaruhi Impor beras Indonesia dengan menggunakan metode regresi linear berganda dan metode ARDL

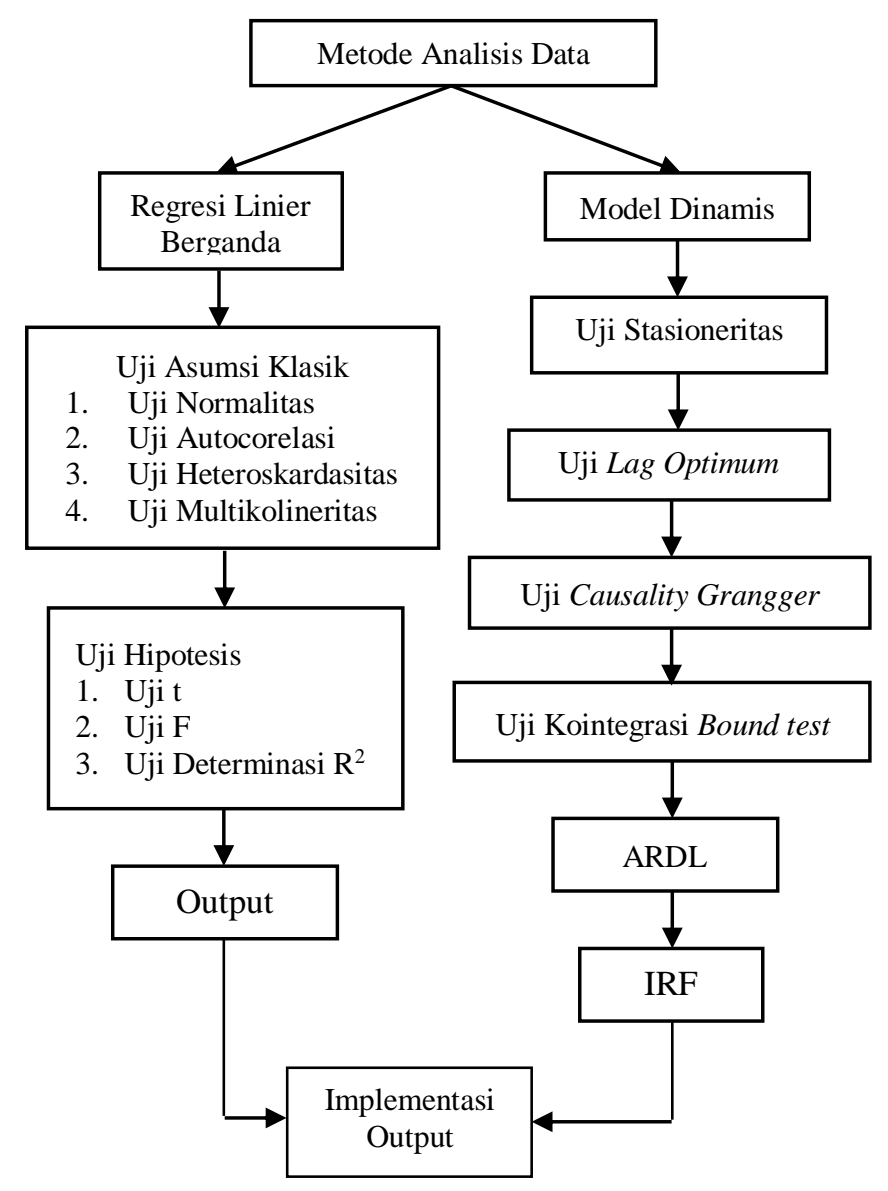

Gambar 1. Kerangka Konseptual

Berdasarkan pada gambar 1 di atas dapat dijelaskan bahwa variabel yang digunakan pada penelitian ini yaitu Inflasi, Nilai Tukar Rupiah dan Harga Eceran sebagai Variabel bebas, sedangkan Impor beras sebagai variabel terikat. Pada penelitian ini, digunakan dua metode analisis yaitu Analisis Regresi Linear Berganda dimana pada analisis ini melihat adakah pengaruh antara variabel bebas dengan variabel terikat, dan Model Dinamis dengan Metode ARDL dimana pada metode ini melihat pengaruh pada jangka pendek dan jangka panjang.

\section{Hipotesis}

Bedasarkan teori, penelitian, dan kerangka berpikir yang telah dipaparkan diatas maka hipotesis dalam penelitian ini adalah :

1) Diduga variabel inflasi berpengaruh signifikan dan positif terhadap impor beras Indonesia.

2) Diduga variabel Nilai Tukar Rupiah berpengaruh signifikan dan positif terhadap Impor Beras Indonesia.

3) Diduga variabel Harga Eceran berpengaruh signifikan dan negatif terhadap Impor Beras Indonesia.

4) Diduga dalam jangka pendek dan jangka panjang variabel Inflasi, Nilai tukar rupiah dan Harga eceran berpengaruh signifikan dan positif terhadap Impor beras Indonesia.

\section{METODE PENELITIAN Jenis dan Sumber Data}

Data yang digunakan dalam penelitian ini dikategorikan sebagai data sekunder (Time Series) yang diperoleh dari beberapa sumber dengan cara mengambil data-data statistik yang telah ada serta dokumen-dokumen lain yang terkait yang diperlukan. Semua data-data tersebut diperoleh dari sumber-sumber dinas terkait yaitu Badan Pusat Statistik (BPS), dan Bank Indonesia (BI). Data yang diambil yaitu data Inflasi, Nilai Tukar Rupiah, Harga Eceran serta data Impor beras. Berbentuk data tahunan yaitu 19 tahun yang dimulai dari tahun 1999 sampai dengan tahun 2017.

\section{Operasional Variabel}

Variabel yang digunakan dalam penelitian ini terbagi menjadi dua variabel, yaitu variabel 
dependen atau variabel yang dijelaskan dan variabel independen atau variabel yang menjelaskan. Adapun operasional variabel penelitian ini adalah :

1. Impor adalah kegiatan memasukkan barangbarang dari suatu negara ke negara lain secara legal. Variabel impor beras pada penelitian ini dinyatakan dalam satuan US Dollar (US\$).

2. Inflasi adalah tingkat perubahan harga secara umum secara terus menerus. Inflasi dalam penelitian ini menggunakan IHK (Indeks Harga Konsumen) dalam satuan persen.

3. Nilai tukar rupiah adalah perbandingan harga mata uang antara satu negara dengan negara lainnya. Satuannya dalam rupiah ( $\mathrm{Rp})$.

4. Harga merupakan kekuatan membayar masyarakat bagi suatu barang per unit. Variabel harga pada penelitian ini adalah harga beras rata-rata yang dinyatakan dalam rupiah per kilogram per tahun ( $\mathrm{Rp} / \mathrm{Kg} / \mathrm{tahun})$.

\section{Metode Analisis Data}

Penelitian ini menganalisis faktor-faktor yang mempengaruhi Impor Beras di Indonesia dengan menggunakan dua metode analisis yaitu analisis Regresi Linear Berganda dan metode analisis ARDL (Autoregressive Distributed Lag).

Untuk mengetahui pengaruh inflasi, nilai tukar rupiah, dan harga beras terhadap impor beras Indonesia maka menggunakan persamaan sebagai berikut:

$$
\mathrm{Y}=\mathrm{a}+\beta_{1} \mathrm{X}_{1}+\beta_{2} \mathrm{X}_{2}+\beta_{3} \mathrm{X}_{3}+\mathrm{e}
$$

Persamaan di atas dalam penelitian ini yang akan menjelaskan keterkaitan antara variabel bebas dengan variabel terikat, dikarenakan variabel yang digunakan satuannya berebeda-beda dimana variabel impor beras dalam bentuk US\$, variabel nilai tukar rupiah dalam bentuk satuan rupiah, variabel harga eceran dalam bentuk satuan $\mathrm{Rp} / \mathrm{kg}$ sedangkan variabel inflasi dalam bentuk satuan persen, maka selanjutnya untuk menyeragamkan menjadi satu ukuran yang sama bagi masing-masing variabel tersebut variabel diatas diubah bentuknya menjadi Log, dengan demikian persamaannya berubah menjadi: $\log Y=a+\beta_{1} \log X_{1}+\beta_{2} \log X_{2}+\beta_{3} \log X_{3}+e$

Dimana :

$\begin{array}{ll}\log Y & : \text { Impor Beras } \\ \text { a } & : \text { Konstanta } \\ \beta_{1} \beta_{2} \beta_{3} & : \text { Koefisien regresi variabel } \\ \log X_{1} & : \text { Inflasi } \\ \log X_{2} & : \text { Nilai Tukar Rupiah terhadap } \\ & \text { Dollar } \\ \log X_{3} & : \text { Harga Eceran } \\ \text { e } & : \text { Variabel gangguan atau residual } \\ & \text { (Standar Error) }\end{array}$

Sedangkan untuk mengetahui tingkat signifikan dari masing-masing koefisien regresi variabel bebas terhadap variabel terikat maka penulis menggunakan uji asumsi klasik, uji statistik t, uji statistik $\mathrm{F}$, dan analisis koefisien determinasi $\left(\mathrm{R}^{2}\right)$.

\section{Uji Normalitas}

Uji normalitas dilakukan untuk menguji apakah didalam model regresi, variabel independen dan dependen mempunyai distribusi normal atau tidak. Uji normalitas bertujuan untuk mengetahui apakah data sudah menyebar secara normal dan mengetahui kenormalan error term dari variabel bebas maupun terikat. Jika data tidak terdistribusi normal maka hasilnya tetap tidak bias, namun tidak lagi efisien.

Metode yang digunakan dalam uji normalitas ini dapat menggunakan metode JarqueBera Test (J-B Test). Hipotesis yang digunakan adalah:

Ho : Data berdistribusi normal

Ha : Data tidak berdistribusi normal

Kriteria pengujian:

a. Ho ditolak, jika nilai probabilitas $<\alpha 5 \%$.

b. Ho diterima, jika nilai probabilitas $>\alpha$ $5 \%$.

\section{Pengujian Asumsi Klasik}

Dalam ilmu ekonometrika agar suatu model dikatakan baik maka perlu dilakukan pengujian sebagai berikut :

\section{Uji Autokorelasi}


Pengujian ini bertujuan untuk mengetahui ada atau tidaknya korelasi antara data dalam variabel pengamatan. Untuk mendeteksi adanya autocorelasi dapat digunakan metode BreuschGodfrey dan sering dikenal dengan nama metode Lagrange Multiplier (LM). Metode ini merupakan pengembangan dari metode Durbin-Watson.

Hipotesis yang digunakan untuk menguji ada tidaknya autocorelasi yaitu :

a. Ho ditolak, jika Obs*R-squared ( $\chi^{2}$ hitung) $>$ ( $\chi^{2}$ tabel $)$, atau probabilitasnya $<\alpha=0.05$. Ini menunjukkan adanya masalah autocorelasi didalam model.

b. Ho diterima, jika Obs*R-squared ( $\chi^{2}$ hitung) $<\left(\chi^{2}\right.$ tabel $)$, atau probabilitas $>\alpha=0.05$. Ini menunjukkan tidak adanya masalah autocorelasi dalam model.

\section{Uji Heteroskedastisitas}

Masalah heteroskedastisitas ini muncul apabila residual dari model regresi yang kita amati memiliki varian yang tidak konstan dari satu observasi ke observasi lain (Hasan, 2002). Artinya, setiap observasi mempunyai reabilitas yang berbeda akibat perubahan dalam kondisi yang melatarbelakangi tidak terangkum dalam spesifikasi model. Padahal salah satu asumsi penting dalam model OLS atau regresi sederhana adalah varian bersifat homoskedastisitas.

Variabel gangguan akan muncul jika data yang diamati berfluktuasi sangat tinggi. Kriteria gejala heteroskedastisitas menggunakan metode Glejser : a) Jika nilai probabiliti $<\alpha=5 \%$ maka : ada gejala heteroskedastisitas, b) Jika nilai probabiliti $>\alpha=5 \%$ maka : tidak ada gejala heteroskedastisitas.

\section{Uji Multikolinearitas}

Prasyarat yang harus terpenuhi dalam model regresiadalah tidak adanya multikolineritas. Uji multikolineritas digunakan untuk mengetahui adanya hubungan linier antar variabel dependent dalam model regresi atau untuk menguji ada tidaknya hubungan yang sempurna atau tidak sempurna diantara beberapa atau semua variabel yang menjelaskan. Ada beberapa cara untuk menganalisis ada atau tidaknya pengaruh multikolineritas dalam penelitian ini yaitu : a. $\mathrm{R}^{2}$ relatif tinggi $(0,70-1,00)$ tetapi hanya sebagian kecil atau bahkan tidak ada variabel bebas yang signifikan menurut $\mathrm{t}$ test, maka diduga terdapat multikolineritas.

b. Koefisien determinasi individual $\left(\mathrm{r}^{2}\right)$ relatif tinggi dari pada koefisien determinasi serentak $\left(\mathrm{R}^{2}\right)$, maka cenderung terdapat multikolineritas.

c. Mengamati nilai Varians Inflation Factor (VIF) pada model regresi, jika VIF $\geq 10$ maka terjadi multikolineritas.

Pada penelitian ini dalam mendeteksi gejala multikolineritas adalah dengan mengamati nilai Varians Inflation Factor (VIF) pada model regresi. Suatu data dapat dikatakan terbebas dari gejala multikolineritas jika nilai VIF antar variabel independent lebih kecil dari 10.

\section{Hipotesis}

Untuk menguji kebenaran model regresi diperlukan pengujian statistik diantaranya :

Uji-t

Uji t-statistik dilakukan untuk menjelaskan pengaruh variabel bebas secara individu memberikan pengaruh atau tidak terhadap variabel terikat. Dengan menggunakan derajat signifikansi $5 \%$, hipotesis yang akan diuji dalam penelitian ini adalah :

Hipotesis 1

H0 : $\beta 1=0$ artinya variabel inflasi tidak berpengaruh signifikan terhadap variabel Impor Beras.

H1 : $\beta 1>0$ artinya variabel inflasi berpengaruh positif dan signifikan terhadap variabel impor beras.

Hipotesis 2

H0 : $\beta 2=0$ artinya variabel nilai tukar rupiah tidak berpengaruh signifikan terhadap variabel impor beras.

H1 : $B 2<0$ artinya variabel nilai tukar rupiah berpengaruh negatif dan signifikan terhadap variabel impor beras.

Hipotesis 3

H0 : $\beta 3=0$ artinya variabel Harga tidak berpengaruh signifikan terhadap variabel impor beras. 
H1 : $B 3>0$ artinya variabel Harga berpengaruh positif dan signifikan terhadap variabel impor beras.

Kriteria uji t-statistik, $\mathrm{H} 1$ diterima dan $\mathrm{H} 0$ ditolak jika nilai t-statistik lebih besar dari nilai ttabel $\mathrm{a}=5 \%$ dan sebaliknya.

\section{Uji-F}

Uji ini digunakan untuk mengetahui pengaruh variabel independen secara signifikan terhadap variabel dependen. Dimana jika $F_{\text {hitung }}>$ $\mathrm{F}_{\text {tabel, }}$, maka $\mathrm{H}_{1}$ diterima atau variabel dependen. Sebaliknya jika $F_{\text {hitung }}<\mathrm{F}_{\text {tabel }}$, maka $\mathrm{H}_{0}$ diterima variabel independen secara bersama-sama tidak memiliki pengaruh terhadap variabel dependen (tidak signifikan) dengan kata lain perubahan yang terjadi pada variabel terikat tidak dapat dijelaskan oleh perubahan variabel independen, dimana tingkat signifikan yang digunakan adalah $5 \%$.

\section{Uji Koefisien Determinasi $\left(\mathbf{R}^{\mathbf{2}}\right)$}

Pada $\mathrm{R}^{2}$ diartikan besarnya presentase sumbangan variabel bebas (X) terhadap variasi (naik-turunnya) variabel terikat (Y) sedangkan lainnya merupakan sumbangan dari faktor lainnya yang tidak termasuk dalam model (Rahim,2013). Nilai koefisien determinasi adalah antara 0 dan 1.

\section{AnalisisModel Dinamis}

Dalam Model Dinamis ada beberapa langkah yang harus dilakukan, langkah-langkah yang harus dilakukan dalam estimasi model dinamis yaitu:

1. Uji Stasioneritas /Unit Root Test

2. Penentuan Panjang Lag / Lag Optimal

3. Uji Kausalitas Grenger

4. Uji Kointegrasi (ARDL pakai Boun Test)

5. Untuk ARDL (Uji Stabilitas ARDL)

Pada penelitian ini Estimasi Model yang digunakan adalah Model ARDL. Berdasarkan hasil uji stasioner terdapat satu variabel yang stasioner di level dan empat variabel yang stasioner di first difference. Karena syarat dari Model ARDL adalah semua variabel harus lulus Stasioner pada Level dan first Difference (1). Dengan prosedur yang digunakan dalam pengujian stasioner adalah prosedur Phillips Perron (PP).
Sebelum melakukan metode analisis ARDL maka harus dilakukan uji terhadap kestasioneran data, uji Lag Optimal, Uji Kausalitas dan Uji Kointegrasi Bound-Test.

\section{Uji Stasioner}

Uji staioneritas dilakukan untuk mengetahui apakah variabel-variabel tersebut stasioner atau tidak. Terdapat beberapa prosedur pengujian unit root, diantaranya adalah Augmented Dickey-Fuller (ADF) dan PhillipsPerron (PP).

Pengujian unit root dengan menggunakan prosedur atau pendekatan Phillips Perron (PP) merupakan pengembangan prosedur Dickey-Fuller (DF) dengan memperbolehkan asumsi adanya distribusi error. Dalam uji DF digunakan asumsi adanya error yang homogen dan independen, sedangkan pada PP dapat mengakomodasi adanya error yang dependen dan terdistribusi secara heterogen. Persamaan dari pendekatan PhilipsPerron (PP) adalah sebagai berikut:

$$
\mathrm{Y}_{\mathrm{t}}=\alpha \mathrm{Y}_{\mathrm{t}-1}+\mathrm{e}_{\mathrm{t}} \quad-1 \leq \alpha \leq 1
$$

Dimana:

$Y_{t} \quad$ : series yang stasioner pada waktu $t=$ $1, \ldots, T$

$\alpha \quad$ : konstanta

$Y_{t-1} \quad$ :proporsi nilai lampau series yang bersangkutan

$e_{\mathrm{t}} \quad$ : nilai residual pada waktu $t$

Apabila suatu data time series tidak stasioner pada level, maka stasioneritas dapat dicari melalui orde selanjutnya, yaitu pada orde first difference, atau orde second difference.

Karena penelitian ini menggunakan metode ARDL, maka seluruh variabel harus stasioner pada tingkat level atau pada tingkat first difference, dan prosedur yang digunakan dalam pengujian stasioner adalah dengan prosedur Phillips Pherron $(P P)$. Hipotesis yang digunakan adalah :

Ho : terdapat unit root (tidak stasioner)

$\mathrm{H}_{1}$ : tidak terdapat unit root (stasioner)

\section{Uji Lag Optimal}


Penetapan lag optimal pada model dilakukan untuk mengetahui kombinasi lag pada model ARDL. Penentuan lag optimal sangat penting dalam model ARDL, karena suatu variabel juga dipengaruhi oleh variabel itu sendiri, selain dipengaruhi oleh variabel lain. Dalam penelitian ini untuk menentukan panjang lag optimal akan menggunakan kriteria Likehood Ratio (LR), Final Prediction erroe (FPE), Akaike Information Criterion (AIC), Schwartz Information Criterion (SIC), Hanna-Quinn Information Criterion (HQ).

Penentuan lag optimal dengan menggunakan kriteria informasi tersebut diperoleh dengan mempunyai tanda bintang paling banyak diantara lag yang diperoleh.

\section{Uji Kausalitas Granger}

Uji Kausalitas Granger merupakan hubungan kausal atau dua arah (Gujarati, 2003). Model dasar:

$$
\begin{aligned}
& X t=\sum_{i=1}^{m} \alpha_{i} Y_{t-i}+\sum_{j=1}^{m} \beta_{j} X_{t-j}+\mu t \\
& Y_{t}=\sum_{i=1}^{m} \alpha_{i} Y_{t-1}+\sum_{j=1}^{m} \beta_{j} X_{t-j}+v t
\end{aligned}
$$

Keterangan:

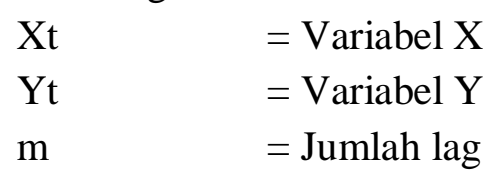

$\mu \mathrm{t}$ dan vt $\quad=$ Variabel pengganggu

$\alpha \operatorname{dan} \beta=$ Koefisien masing-masing variabel diasumsikan bahwa $\mu \mathrm{t}$ dan vt tidak berkorelasi.

Menurut Gujarati (2003), pada uji kausalitas ada empat kemungkinan mengenai nilainilai koefisiensi-koefesiensi yaitu:

1. $\sum_{i=1}^{m} \alpha_{i} \neq 0$ dan $\sum_{j=1}^{m} \beta_{i}=0$

Maka terdapat Kausalitas satu arah dari variabel $\mathrm{X}$ terhadap variabel $\mathrm{Y}$.

2. $\sum_{i=1}^{m} \alpha_{i}=o$ dan $\sum_{j=1}^{m} \beta_{i} \neq 0$

Maka terdapat Kausalitas satu arah dari variabel X terhadap variabel Y.
3. $\sum_{i=1}^{m} \alpha_{i}=o$ dan $\sum_{j=1}^{m} \beta_{i}=0$

Maka tidak terdapat Kausalitas baik antara variabel $\mathrm{X}$ dan $\mathrm{Y}$ maupun antara variabel $\mathrm{Y}$ terhadap variabel $\mathrm{X}$.

4. $\sum_{\mathrm{i}=1}^{\mathrm{m}} \alpha_{\mathrm{i}} \neq \mathrm{o}$ dan $\sum_{\mathrm{j}=1}^{\mathrm{m}} \beta_{\mathrm{i}} \neq 0$

Maka terdapat Kausalitas dua arah antara $X$ terhadap $\mathrm{Y}$ maupun antara variabel $\mathrm{Y}$ terhadap variabel $X$.

Untuk melihat kausalitas grenger dapat dilihat dengan membandingkan F-statistik dengan nilai kritis F-tabel pada tingkat kepercayaan (1\%, $5 \%$, atau 10\%). Kriteria Penolakan dan Penerimaan:

F-stat $>$ F-tabel $=$ Ho ditolak

F-stat $<$ F-tabel $=$ Ho diterima

\section{Uji Kointegrasi Bound Test}

Uji kointegrasi dilakukan untuk menguji apakah variabel-variabel yang tidak stasioner pada data level terkointegrasi antara satu variabel dengan variabel yang lain. Kointegrasi ini terbentuk apabila kombinasi antara variabelvariabel yang tidak stasioner menghasilkan variabel yang stasioner. Apabila terdapat persamaan sebagai berikut:

$\mathrm{y}_{\mathrm{t}}=\beta_{0}+\beta_{1} \mathrm{x}_{1}+\mathrm{e}_{\mathrm{t}}$

Maka, error dari persamaan tersebut dapat ditulis menjadi:

$e_{t}=y_{t}-\beta_{0}-\beta_{1} x_{1}$

dengan catatan bahwa $e_{t}$ merupakan kombinasi linear dari $\mathrm{x}_{1}$ dan $\mathrm{x}_{2}$.

Konsep kointegrasi yang diperkenalkan oleh Engle dan Granger pada tahun 1987 mensyaratkan bahwa $e_{t}$ haruslah stasioner pada I(0) untuk dapat menghasilkan keseimbangan jangka panjang (Ginting, 2008). Pada penelitian ini uji kointegrasi dilakukan dengan menggunakan metode Bound Testing Cointegration dengan pendekatan ARDL yang diperkenalkan oleh Pesara dan Shin (2001). Metode tersebut dilakukan dengan cara membandingkan nilai Fstatistik hitung dengan nilai krisis. Apabila nilai F- 
statistik berad dibawah lower bound, maka dapat disimpulkan bahwa tidak terjadi kointegrasi. Apabila nilai F-statistik berada diatas upper bound, maka dapat disimpulkan terjadi kointegrasi. Namun apabila F-statistik berada diantara lower bound dan upper bound maka hasilnya adalah tidak dapat disimpulkan.

\section{Metode Model ARDL}

Model ARDL (Autoregressive Distributed Lag) adalah pengaruh variabel $\mathrm{X}$ dan $\mathrm{Y}$ dari waktu ke waktu termasuk pengaruh variabel $\mathrm{Y}$ dari masa lampau terhadap nilai Y masa sekarang.

Uji kointegrasi dalam metode ini dilakukan dengan membandingkan nilai F-statistik dengan nilai F-tabel. Langkah pertama yang dilakukan dalam pendekatan ARDL Bound test untuk melihat F-statistik yang diperoleh. F-statistik yang diperoleh akan menjelaskan ada atau tidaknya hubungan jangka panjang antara variabel. Hipotesis dalam uji $\mathrm{F}$ ini sebagai berkut:

$\mathrm{H}_{0}=\alpha_{1}=\alpha_{2}=\alpha_{\mathrm{n}}=0$; tidak terdapat hubungan jangka panjang,

$\mathrm{H}_{1}=\alpha_{1} \neq \alpha_{2} \neq \alpha_{\mathrm{n}} \neq 0$; terdapat hubungan jangka panjang,

Jika nilai F-statistik yang diperoleh dari hasil pengujian Bound Test lebih besar dari nilai upper critical value $\mathrm{I}(1)$ maka tolak $\mathrm{H}_{0}$, sehingga dalam model terdapat hubungan jangka panjang atau terdapat kointegrasi, jika nilai F-statistik berada dibawah nilai lower critical value $\mathrm{I}(0)$ maka tidak tolah $\mathrm{H}_{\mathrm{o}}$, sehingga dalam model tidak terdapat hubungan jangka panjang atau tidak terdapat kointegrasi, jika nilai F-statistik berada diantara nilai upper dan lowe critical value maka hasilnya tidak dapat disimpulkan.

Secara umum model ARDL dalam persamaan jangka panjang dapat dituliskan sebagai berikut:

$$
\begin{aligned}
Y_{t}=\alpha_{0}+\alpha_{1} t & +\sum_{i=1}^{p} \alpha_{2}+Y_{t-i}+\sum_{i=0}^{q} \alpha_{3} X_{1 t-i} \\
& +\sum_{i=0}^{r} \alpha_{4} X_{2 t-i}+\sum_{i=0}^{s} \alpha_{5} X_{3 t-i}+\text { et }
\end{aligned}
$$

Pendekatan dengan menggunakan model ARDL mensyaratkan adanya lag seperti yang ada pada persamaan diatas. Pemilihan lag yang tepat untuk model dapat dipilih menggunakan basis Schawrtz-Bayesian Criteria (SBC), Akaike Information Criteria (AIC), atau menggunakan informasi kriteria yang lain, model yang baik memiliki nilai informasi kriteria yang terkecil. Langkah selanjutnya dalam metode ARDL adalah mengestimasi parameter dalam short run atau jangka pendek.

\section{HASIL DAN PEMBAHASAN}

Uji Normalitas

Setelah dilakukan pengujian dengan menggunakan E-Views, maka diperoleh hasil sebagai berikut:

\section{Gambar 2}

Histogram-Uji Normalitas

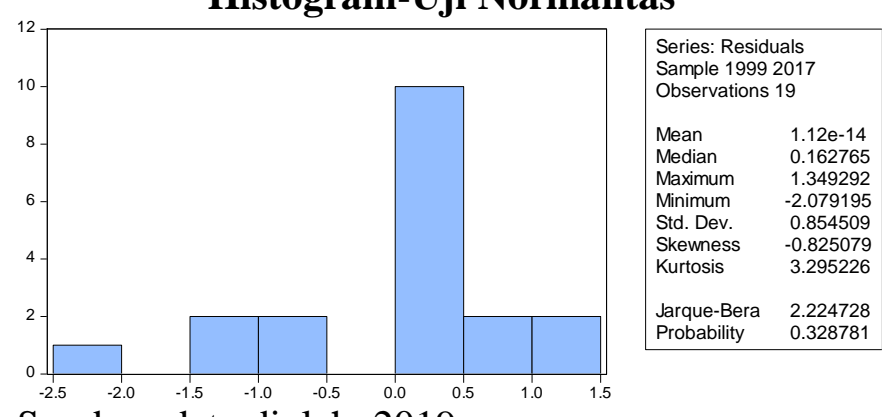

Sumber: data diolah, 2019

Gambar 2 menunjukkan bahwa nilai JB hitung sebesar 2,224728, dan nilai kepercayaan $\alpha=5 \%(0,05)$. Dengan nilai JB hitung $(2,224728)>$ nilai $\alpha(0,05)$ dan dapat disimpulkan bahwa data penelitian ini berdistribusi normal. Selain itu dapat dilihat dari nilai probabilitas yang lebih besar dari $\alpha=5 \%(0,05)$, dengan nilai probabilitas sebesar 0,328781 .

\section{Uji Asumsi Klasik}

\section{Uji Autokorelasi}

Dalam penelitian ini pengujian autokorelasi menggunakan metode Lagrange Multiplier Test (LM) dengan lag residual yang digunakan yaitu lag 2. Untuk mengetahui apakah dalam model penelitian, variabel terbebas dari autokorelasi maka dapat diketahui dengan melihat dan membandingkan nilai Probabiliti Chi-Square dengan nilai kepercayaan $\alpha=5 \%(0,05)$. Menurut Widarjono (2009), "Jika nilai probability ChiSquare $>\alpha=5 \%(0,05)$, maka data terbebas dari 
autokorelasi”. Hasil yang diperoleh adalah sebagai berikut.

\section{Tabel 3}

Uji Autokorelasi

\begin{tabular}{|l|l|l|l|}
\hline F-statistic & 2.297210 & Prob. F(2,12) & 0.1399 \\
\hline Obs*R-squared & 4.961459 & $\begin{array}{l}\text { Prob. Chi- } \\
\text { Square(2) }\end{array}$ & 0.0837 \\
\hline
\end{tabular}

Sumber: data diolah, 2019

Tabel 4.1 menunjukkan bahwa nilai Prob. Chi-Square sebesar 0,0837, dan nilai kepercayaan $\alpha=5 \% \quad(0,05)$. Dengan nilai prob. Chi-Square $(0,0837)>\alpha=5 \%(0,05)$ dan dapat disimpulkan bahwa data penelitian ini terbebas dari autokorelasi.

\section{Uji Heteroskedastisitas}

Masalah heteroskedastisitas dapat dilihat dengan banyak metode salah satunya dengan metode Glejser. Setelah dilakukan pengujian maka hasil yang diperoleh adalah sebagai berikut.

\section{Tabel 4}

Uji Heteroskedastisitas dengan metode Glejser

\begin{tabular}{|c|c|}
\hline \multirow{2}{*}{\multicolumn{2}{|c|}{$\begin{array}{l}\text { Test Equation: } \\
\text { Denendent Variable ARFSID }\end{array}$}} \\
\hline & \\
\hline \multicolumn{2}{|l|}{ Method: Least Squares } \\
\hline \multicolumn{2}{|l|}{ Date: 05/07/19 Time: $02: 30$} \\
\hline \multicolumn{2}{|l|}{ Sample: 19992017} \\
\hline \multicolumn{2}{|l|}{ Included observations: 19} \\
\hline Variable & Coefficient Std. Error t-Statistic Prob. \\
\hline $\mathrm{C}$ & \begin{tabular}{|l|l|l|l|l|}
8.218465 & 8.622381 & 0.953155 & 0.3556 \\
\end{tabular} \\
\hline LOG(INFLASI) & $\begin{array}{lllll}0.054980 & 0.261261 & 0.210442 & 0.8362 \\
\end{array}$ \\
\hline LOG(NILAI_TUKAR_RUPIAH) & \begin{tabular}{ll|l|l|l|l|} 
I) -1.401008 & 1.239330 & -1.130455 & 0.2760 \\
\end{tabular} \\
\hline LOG(HARGA_ECERAN) & \begin{tabular}{|l|l|l|l|l|l}
0.394277 & 0.379967 & 1.037659 & 0.3159 \\
\end{tabular} \\
\hline
\end{tabular}

Sumber: data diolah, 2019

Pada tabel 4.2 diketahui bahwa nilai probabilitas variabel Inflasi $(0,8362)>\alpha=5 \%$ $(0,05)$, nilai probabiliti dari variabel Nilai tukar rupiah $(0,2760)>\alpha=5 \%(0,05)$ dan nilai probabiliti dari variabel Harga eceran $(0,3159)>\alpha=5 \%$ $(0,05)$. Maka pada penelitian ini dapat disimpulkan terbebas dari heteroskedastisitas.

\section{Uji Multikolinearitas}

Adapun hasil yang diperoleh adalah sebagai berikut.

\section{Tabel 5}

Matriks Korelasi

\begin{tabular}{|l|l|l|l|}
\hline & INFLASI & $\begin{array}{l}\text { NILAI_TUKAR_RAA } \\
\text { RUPIAH }\end{array}$ & $\begin{array}{l}\text { HARGA_ } \\
\text { ECERAN }\end{array}$ \\
\hline INFLASI & 1 & -0.194103 & -0.437657 \\
\hline $\begin{array}{l}\text { NILAI_TUKAR_ } \\
\text { RUPIAH }\end{array}$ & -0.194103 & 1 & 0.784892 \\
\hline $\begin{array}{l}\text { HARGA_ECERA } \\
\text { N }\end{array}$ & -0.437657 & 0.784892 & 1 \\
\hline
\end{tabular}

Sumber: data diolah, 2019

Dari tabel diatas dapat diketahui bahwa tidak terdapat masalah multikolinearitas karena nilai matriks korelasi semua variabel independen (Inflasi, Nilai Tukar Rupiah dan Harga Eceran) kurang dari nilai 0,8 .

\section{Uji Hipotesis}

Adapun model yang digunakan merupakan regresi data sekunder dengan menggunakan Ordinary Least Square (OLS) dan hasil yang didapatkan sebagai berikut:

\section{Tabel 6}

\section{Hasil Regresi dengan OLS}

\begin{tabular}{|c|c|c|c|c|}
\hline \multicolumn{5}{|c|}{ Dependent Variable: LOG(IMPOR_BERAS) } \\
\hline \multicolumn{5}{|l|}{ Method: Least Squares } \\
\hline \multicolumn{5}{|l|}{ Date: 05/07/19 Time: 02:39 } \\
\hline \multicolumn{5}{|l|}{ Sample: 19992017} \\
\hline \multicolumn{5}{|l|}{ Included observations: 19} \\
\hline Variable & Coefficien & $\begin{array}{l}\text { Std. } \\
\text { Error }\end{array}$ & t-Statistic & Prob. \\
\hline C & 25.11893 & 13.75219 & 1.826540 & 0.0877 \\
\hline LOG(INFLASI) & -1.013390 & 0.416696 & -2.431964 & 0.0280 \\
\hline LOG(NILAI_TUKAR_RUPIAH) & -3.987606 & 1.976659 & -2.017346 & 0.0619 \\
\hline LOG(HARGA_ECERAN) & 2.081532 & 0.606026 & 3.434727 & 0.0037 \\
\hline
\end{tabular}

Sumber: data diolah, 2019

$\log (\operatorname{Imporberas})=25,11893-1,013390(\log (\operatorname{Inflasi}))-$ $3,987606(\log ($ NilaiTukarRupiah $))+$ $2,081532(\log ($ HargaEceran $))+e$

1) Konstanta (C) $=25,11893$, pada saat Inflasi, Nilai Tukar Rupiah dan Harga Eceran konstan, maka Impor Beras tetap Konstan sebesar 25,111893 .

2) Inflasi $=-1,013390$, jika Inflasi meningkat $1 \%$, maka akan menyebabkan Impor Beras menurun sebesar $1,01 \%$.

3) Nilai Tukar Rupiah $=-3,987606$, jika Nilai Tukar Rupiah meningkat 1 Rp, maka akan menyebabkan Impor Beras menurun sebesar 3,98 Rp. 
4) Harga Eceran $=2,081532$, jika Harga Eceran meningkat $1 \mathrm{Rp}$, maka akan menyebabkan Impor Beras meningkat sebesar 2,08 Rp.

\section{Uji-t dan Interprestasi}

Pengujian ini dilakukan untuk melihat apakah variabel independen (Inflasi, Nilai tukar rupiah dan Harga eceran) berpengaruh secara parsial (individu) terhadap variabel dependen (Impor beras). Dengan kata lain, uji ini untuk melihat masing-masing variabel bebas terhadap variabel terikat.

Kemudian membandingkan masing-masing nilai t-statistik dari hasil regresi dengan nilai ttabel dan disimpulkan dengan hipotesis. Pada tingkat signifikansi $\alpha=5 \%$, maka diperoleh t-tabel 2,13145. Setelah dilakukan regres dengan menggunakan E-Views 9.0 diperoleh nilai tstatistik sebagai berikut:

Tabel 7

\section{Hasil Uji-t}

\begin{tabular}{|l|l|l|l|}
\hline Variable & $\mathrm{t}$-Statistic & t-tabel & Prob. \\
\hline C & 1.826540 & & 0.0877 \\
\hline LOG(INFLASI) & - & 2.13145 & \\
\hline LOG(NILAI_TUKAR_RUPIAH) & 2.017346 & & 0.0619 \\
\hline LOG(HARGA_ECERAN) & 3.434727 & 2.13145 & 0.0037 \\
\hline
\end{tabular}

Sumber: data diolah, 2019

\section{1) Inflasi}

Setelah melihat hasil di tabel 4.5 diketahui bahwa t-statistik dari variabel Inflasi sebesar 2,431964, sedangkan nilai t-tabel 2,13145.

Dengan hipotesis:

Ho : $\beta=0$, berarti secara parsial tidak ada pengaruh signifikan dari variabel Inflasi terhadap variabel Impor Beras.

Ha : $\beta \neq 0$, berarti secara parsial ada pengaruh yang signifikan dari variabel Inflasi terhadap variabel Impor Beras.

Karena t-statistik $(-2,431964)>$ t-tabel $(2,13145)$ yang berarti Ha diterima. Maka dapat disimpulkan bahwa secara parsial terdapat pengaruh signifikan dan negatif antara variabel Inflasi dengan variabel Impor Beras. Hasil ini diperkuat dengan Probabilitas Inflasi $(0,0280)<$ $\alpha=5 \%(0,05)$. Maka dapat disimpulkan bahwa secara parsial variabel Inflasi berpengaruh secara negatif dan signifikan terhadap variabel Impor Beras.

\section{2) Nilai Tukar Rupiah}

Setelah melihat hasil pada tabel 4.5 diketahui bahwa t-statistik dari Nilai Tukar Rupiah sebesar -2,017346, sedangkan nilai t-tabel 2,13145 .

Dengan Hipotesis:

Ho : $\beta=0$, berarti secara parsial tidak ada pengaruh signifikan dari variabel Nilai Tukar Rupiah terhadap variabel Impor Beras.

Ha : $\beta \neq 0$, berarti secara parsial ada pengaruh yang signifikan dari variabel Nilai Tukar Rupiah terhadap variabel Impor Beras.

Karena t-statistik $(-2,017346)<\mathrm{t}$-tabel $(2,14479)$ yang berarti Ho diterima. Maka dapat disimpulkan bahwa secara parsial tidak ada pengaruh secara signifikan antara variabel Nilai Tukar Rupiah dengan variabel Impor Beras. Hasil ini diperkuat dengan nilai Probabilitas Nilai Tukar Rupiah $(0,0619)>\alpha=5 \%(0,05)$. Maka dapat disimpulkan secara parsial variabel Nilai Tukar Rupiah tidak ada pengaruh signifikan dan negatif terhadap variabel Impor Beras.

3) Harga Eceran

Setelah melihat hasil pada tabel 4.5 diketahui bahwa t-statistik variabel Harga Eceran sebesar 3,434727, sedangkan nilai t-tabel 2,13145. Dengan Hipotesis:

Ho : $\beta=0$, berarti secara parsial tidak ada pengaruh signifikan dari variabel Harga Eceran terhadap variabel Impor Beras.

Ha : $\beta \neq 0$, berarti secara parsial ada pengaruh yang signifikan dari variabel Harga Eceran terhadap variabel Impor Beras.

Karena t-statistik $(3,434727)>t$-tabel $(2,14479)$ yang berarti Ha diterima. Maka dapat disimpulkan bahwa secara parsial terdapat pengaruh yang signifikan antara variabel Harga Eceran dengan variabel Impor Beras. Hasil ini diperkuat dengan nilai Probabiliti Harga Eceran $(0,0037)<\alpha=5 \%(0,05)$. Maka dapat disimpulkan bahwa secara parsial variabel Harga Eceran berpengaruh signifikan dan positif terhadap Variabel Impor Beras. 


\section{Uji F dan Interprestasi}

Pengujian ini dilakukan untuk mengetahui dan melihat pengaruh antara variabel independen (Inflasi, Nilai Tukar Rupiah dan Harga Eceran) terhadap variabel dependen (Impor Beras) secara simultan atau bersama-sama. Dari hasil regresi diperoleh nilai F-statistik sebesar 9,611139. Pada tingkat signifikansi $\alpha=5 \%, \mathrm{k}=4, \mathrm{n}=19$, sehingga diperoleh nilai F-tabel dengan nilai df yaitu 3,29.

Tabel 8

\section{Hasil Uji F}

\begin{tabular}{|l|r|}
\hline F-statistic & 9.611139 \\
\hline Prob(F-statistic) & 0.000870 \\
\hline
\end{tabular}

Sumber: data diolah, 2019

Dengan Hipotesis:

Ho : $\beta=0$, berarti tidak ada pengaruh signifikan dari variabel Inflasi, Nilai Tukar Rupiah dan Harga Eceran terhadap variabel Impor Beras secara simultan (bersama-sama).

Ha : $\beta \neq 0$, berarti ada pengaruh yang signifikan dari variabel Inflasi, Nilai Tukar Rupiah dan Harga Eceran terhadap Impor Beras secara simultan (bersama-sama).

Diketahui bahwa nilai F-statistik $(9,611139)>$ F-tabel $(3,29)$ maka dapat disimpulkan bahwa secara simultan variabel Inflasi, Nilai Tukar Rupiah dan Harga Eceran berpengaruh positif dan signifikan terhadap Impor Beras.

\section{Uji Koefisien Determinasi $\left(\mathbf{R}^{\mathbf{2}}\right)$ dan Interprestasi}

Berdasarkan pengolahan data dengan menggunakan E-Views 9.0, diperoleh nilai $\mathrm{R}^{2}$ sebesar 0,589354. Nilai ini menjelaskan bahwa $58 \%$ variabel Impor Beras di Indonesia mampu dijelaskan oleh variabel Inflasi, Nilai Tukar Rupiah dan Harga Eceran. Sedangkan 42\% variabel Impor Beras dapat dijelaskan oleh variabel lain yang tidak termasuk dalam penelitian ini.

\section{Model Dinamis}

Pada penelitian ini juga menggunakan analisis model dinamis yaitu ARDL. Sebelum melakukan metode analisis ARDL, maka terlebih dahulu dilakukan langkah-langkah dalam model dinamis, langkah-langkah yang harus dilakukan dalam estimasi model ini yaitu

\section{Uji Stasioneritas}

Tahap pertama yang dilakukan adalah melihat uji stasioneritas, untuk mengetahui pada derajat keberapa data akan stasioner. penelitian ini menggunakan uji akar unit dengan metode $U j i$ Phillps Pherron (PP):

Tabel 9

Nilai Uji Akar Unit dengan Metode Uji PP pada Tingkat Level

\begin{tabular}{|l|r|r|r|c|}
\hline Variabel & $\begin{array}{c}\text { Nilai PP } \\
\text { Test }\end{array}$ & $\begin{array}{c}\text { Nilai } \\
\text { Kritis } \\
\boldsymbol{\alpha}=\mathbf{5 \%}\end{array}$ & Probabilitas & Keputusan \\
\hline Inflasi & 3,895345 & 0,05 & 0,0093 & Stasioner \\
\hline $\begin{array}{l}\text { Nilai } \\
\text { Tukar } \\
\text { Rupiah }\end{array}$ & 0,753597 & 0,05 & 0,8081 & $\begin{array}{c}\text { Tidak } \\
\text { Stasioner }\end{array}$ \\
\hline $\begin{array}{l}\text { Harga } \\
\text { Eceran }\end{array}$ & 0,878487 & 0,05 & 0,9925 & $\begin{array}{c}\text { Tidak } \\
\text { Stasioner }\end{array}$ \\
\hline $\begin{array}{l}\text { Impor } \\
\text { Beras }\end{array}$ & 2,856247 & 0,05 & 0,0704 & $\begin{array}{c}\text { Tidak } \\
\text { Stasioner }\end{array}$ \\
\hline
\end{tabular}

Sumber: data diolah, 2019

Dari tabel 9 dapat dilihat bahwa nilai Probabilitas masing-masing variabel pada tingkat signifikansi $\alpha=5 \%$ menunjukkan variabel yang stasioner yaitu variabel Inflasi, karena nilai probabilitas dari Inflasi sebesar $0,0093<\alpha=5 \%$ $(0,05)$. Sedangkan variabel Nilai Tukar Rupiah, Harga Eceran dan Impor Beras tidak stasioner, karena nilai probabilitasnya lebih besar dari nilai tingkat kepercayaan $\alpha=5 \%(0,05)$. sehingga selanjutnya dilakukan stasioner pada tingkat differencing 1 .

\section{Tabel 10}

Nilai Uji Akar Unit dengan Metode Uji PP pada Tingkat Differencing1

\begin{tabular}{|l|r|r|r|l|}
\hline Variabel & $\begin{array}{c}\text { Nilai PP } \\
\text { Test }\end{array}$ & $\begin{array}{c}\text { Nilai } \\
\text { Kritis } \\
\boldsymbol{\alpha = 5 \%}\end{array}$ & Probabilitas & Keputusan \\
\hline Inflasi & $\begin{array}{r}\text { - } \\
12,06016\end{array}$ & 0,05 & 0,0000 & Stasioner \\
\hline $\begin{array}{l}\text { Nilai } \\
\text { Tukar } \\
\text { Rupiah }\end{array}$ & $-3,310037$ & 0,05 & 0,0308 & Stasioner \\
\hline
\end{tabular}




\begin{tabular}{|l|r|r|r|l|}
\hline $\begin{array}{l}\text { Harga } \\
\text { Eceran }\end{array}$ & 3,305519 & 0,05 & 0,0311 & Stasioner \\
\hline $\begin{array}{l}\text { Impor } \\
\text { Beras }\end{array}$ & $-8,850974$ & 0,05 & 0,0000 & Stasioner \\
\hline
\end{tabular}

Sumber: data diolah, 2019

Berdasarkan tabel 10 dapat dilihat bahwa nilai Probabilitas dari masing-masing variabel dibawah $\alpha=5 \%(0,05)$ dan dapat disimpulkan bahwa semua variabel sudah stasioner pada differensing tingkat pertama dan tidak ada satu variabel pun yang derajat kebebasannya pada differensing2.

\section{Uji Lag Optimal}

Tahap selanjutnya yang digunakan pada penelitian ini adalah Uji Lag Optimal. Dalam penelitian ini untuk menentukan panjang lag optimal akan menggunakan Kriteria Likehood Ratio (LR), Final Prediction Erroe (FPE), Akaike Information Criterion (AIC), Schwartz Information Criterion (SIC), Hanna-Quinn Information Criterion (HQ). Penentuan lag optimal dengan menggunakan kriteria informasi tersebut diperoleh dengan mempunyai tanda bintang paling banyak diantara lag yang diperoleh. Hasil Lag Optimal dapat dilihat pada tabel berikut:

\section{Tabel 11}

\section{Hasil Lag Optimal}

\begin{tabular}{|c|c|c|c|c|c|c|}
\hline Lag & LogL & LR & FPE & AIC & SC & HQ \\
\hline 0 & 740.1237 & NA & $9.50 \mathrm{e}+30$ & 82.68041 & 82.87827 & 82.70769 \\
\hline 1 & 688.7526 & $74.20272 *$ & $1.98 \mathrm{e}+29 *$ & $78.75028 *$ & $79.73959 *$ & $78.88670 *$ \\
\hline
\end{tabular}

Sumber: data diolah, 2019

Berdasarkan tabel 11 dapat dilihat bahwa nilai kriteria LR, FPE, AIC, SC dan HQ lag dengan tanda bintang yang banyak terdapat pada lag 1.

\section{Uji Kausalitas Granger}

Tahap selanjutnya yang dilakukan adalah Uji Kausalitas Granger. Uji Kausalitas adalah hubungan dua arah yang tidak di asumsikan dengan variabel bebas dana variabel terikat. Hasil uji kausalitas dapat dilihat dengan membandingkan nilai probabiliti lebih kecil dari nilai $\alpha=5 \%$. Jika Ha diterima maka terdapat hubungan kausalitas dua arah antar variabel, sedangkan jika Ho diterima maka tidak terdapat kausalitas. Adapun panjang lag yang digunakan yaitu lag 1. Hasil dari uji kausalitas dapat dilihat pada tabel berikut:

\section{Tabel 12}

\section{Hasil Uji Kausalitas}

\begin{tabular}{|c|c|c|c|}
\hline \multicolumn{4}{|l|}{ Pairwise Granger Causality Tests } \\
\hline \multicolumn{4}{|l|}{ Date: 05/07/19 Time: 05:04 } \\
\hline \multicolumn{4}{|l|}{ Sample: 19992017} \\
\hline \multicolumn{4}{|l|}{ Lags: 1} \\
\hline Null Hypothesis: & Obs & $\begin{array}{c}\mathrm{F}- \\
\text { Statistic }\end{array}$ & Prob. \\
\hline $\begin{array}{l}\text { NILAI_TUKAR_RUPIAH does not Granger } \\
\text { Cause INFLASI }\end{array}$ & 18 & 4.45283 & 0.0520 \\
\hline \multicolumn{2}{|l|}{$\begin{array}{l}\text { INFLASI does not Granger Cause } \\
\text { NILAI_TUKAR_RUPIAH }\end{array}$} & 0.20790 & 0.6549 \\
\hline $\begin{array}{l}\text { HARGA_ECERAN does not Granger Cause } \\
\text { INFLASI }\end{array}$ & 18 & 8.48189 & 0.0107 \\
\hline \multicolumn{2}{|l|}{$\begin{array}{l}\text { INFLASI does not Granger Cause } \\
\text { HARGA_ECERAN }\end{array}$} & 3.01104 & 0.1032 \\
\hline $\begin{array}{l}\text { IMPOR_BERAS does not Granger Cause } \\
\text { INFLASI }\end{array}$ & 18 & 0.90096 & 0.3576 \\
\hline \multicolumn{2}{|l|}{ INFLASI does not Granger Cause IMPOR_BERAS } & 0.00079 & 0.9779 \\
\hline $\begin{array}{l}\text { HARGA_ECERAN does not Granger Cause } \\
\text { NILAI_TUKAR_RUPIAH }\end{array}$ & 18 & 3.62080 & 0.0764 \\
\hline \multicolumn{2}{|l|}{$\begin{array}{l}\text { NILAI_TUKAR_RUPIAH does not Granger Cause } \\
\text { HARGA_ECERAN }\end{array}$} & 0.00040 & 0.9842 \\
\hline $\begin{array}{l}\text { IMPOR_BERAS does not Granger Cause } \\
\text { NILAI_TUKAR_RUPIAH }\end{array}$ & 18 & 1.42014 & 0.2519 \\
\hline \multicolumn{2}{|l|}{$\begin{array}{l}\text { NILAI_TUKAR_RUPIAH does not Granger Cause } \\
\text { IMPOR_BERAS }\end{array}$} & $1.0 \mathrm{E}-05$ & 0.9975 \\
\hline $\begin{array}{l}\text { IMPOR_BERAS does not Granger Cause } \\
\text { HARGA_ECERAN }\end{array}$ & 18 & 0.62209 & 0.4426 \\
\hline \begin{tabular}{|l} 
HARGA_ECERAN does not Granger Cause \\
IMPOR_BERAS
\end{tabular} & & 1.59418 & 0.2260 \\
\hline
\end{tabular}

Sumber: data diolah, 2019

\section{1) Nilai Tukar dan Inflasi}

Berdasarkan tabel 4.10 hasil yang didapatkan yaitu pada lag 1 dengan $\alpha=5 \%(0,05)$, Nilai Tukar Rupiah terhadap Inflasi tidak mempengaruhi karena nilai Probabiliti Nilai Tukar Rupiah sebesar 0,0520 > 0,05, dan Inflasi terhadap Nilai Tukar Rupiah juga tidak saling mempengaruhi karena nilai Probabiliti Inflasi sebesar 0,6549>0,05. Dapat disimpulkan bahwa 
Ho diterima yang berarti Nilai Tukar Rupiah dan Inflasi kedua variabel tidak terdapat hubungan kausalitas atau hubungan dua arah.

\section{2) Harga Eceran dan Inflasi}

Berdasarkan tabel 4.10 hasil yang didapatkan yaitu pada lag 1 dengan $\alpha=5 \%(0,05)$, Harga Eceran terhadap Inflasi dipengaruhi karena nilai probabiliti Harga Eceran sebesar 0,0107< 0,05, sedangkan Inflasi terhadap Harga Eceran tidak saling mempengaruhi karena nilai probabiliti Inflasi sebesar 0,1032>0,05, terdapat hubungan satu arah. Maka dapat disimpulkan bahwa Ho diterima yang berarti tidak terdapat hubungan kausalitas antara Harga Eceran dan Inflasi.

3) Impor Beras dan Inflasi

Berdasarkan tabel 4.9 hasil yang didapatkan yaitu pada lag 1 dengan $\alpha=5 \%(0,05)$, Impor Beras terhadap Inflasi tidak mempengaruhi karena nilai probabiliti Impor Beras sebesar 0,3576> 0,05, dan Inflasi terhadap Impor Beras juga tidak saling mempengaruhi karena nilai probabiliti Inflasi sebesar 0,9779>0,05. Maka dapat disimpulkan bahwa Ho diterima yang berarti tidak terdapat hubungan kausalitas antara variabel Impor Beras dan Inflasi.

4) Harga Eceran dan Nilai Tukar Rupiah

Berdasarkan tabel 4.10 hasil yang didapatkan yaitu pada lag 1 dengan $\alpha=5 \%(0,05)$, Harga Eceran terhadap Nilai Tukar Rupiah tidak mempengaruhi karena nilai probabiliti Harga Eceran sebesar 0,0764> 0,05, dan Nilai Tukar Rupiah terhadap Harga Eceran juga tidak saling mempengaruhi karena nilai probabiliti Nilai Tukar Rupiah sebesar 0,9842> 0,05. Maka dapat disimpulkan bahwa Ho diterima yang berarti tidak terdapat hubungan kausalitas antara variabel Harga Eceran dan Nilai Tukar Rupiah.

5) Impor Beras dan Nilai Tukar Rupiah

Berdasarkan tabel 4.10 hasil yang didapatkan yaitu pada lag 1 dengan $\alpha=5 \%(0,05)$, Impor Beras terhadap Nilai Tukar Rupiah tidak mempengaruhi karena nilai probabiliti Impor Beras sebesar 0,2519> 0,05, dan Nilai Tukar Rupiah terhadap Impor Beras juga tidak saling mempengaruhi karena nilai probabiliti Nilai Tukar
Rupiah sebesar 0,9975> 0,05. Maka dapat disimpulkan bahwa Ho diterima yang berarti tidak terdapat hubungan kausalitas antara variabel Impor Beras dan Nilai Tukar Rupiah.

6) Impor Beras dan Harga Eceran

Berdasarkan tabel 4.10 hasil yang didapatkan yaitu pada lag 1 dengan $\alpha=5 \%(0,05)$, Impor Beras terhadap Harga Eceran tidak mempengaruhi karena nilai probabiliti Impor Beras sebesar 0,4426> 0,05, dan Harga Eceran terhadap Impor Beras juga tidak saling mempengaruhi karena nilai probabiliti Harga Eceran sebesar 0,2260> 0,05. Maka dapat disimpulkan bahwa Ho diterima yang berarti tidak terdapat hubungan kausalitas antara variabel Impor Beras dan Harga Eceran.

\section{Uji Kointegrasi Bound Test}

Tahap berikutnya adalah pengujian kointegrasi pada model. (Pesaran \& Shin, 2001) mengemukakan bahwa uji kointegrasi bertujuan untuk menentukan apakah variabel-variabel yang tidak stasioner terkointegrasi atau tidak. Uji kointegrasi yang digunakan dalam penelitian ini menggunakan pendekatan Bound Test, dengan membandingkan nilai F-statistik > I0 Bound. Hasil pengujian kointegrasi dengan menggunakan pendekatan Bound test dapat dilihat pada tabel berikut:

Tabel 13

Hasil Bound Test

\begin{tabular}{|l|c|c|}
\hline Test Statistic & Value & k \\
\hline F-statistic & 5.596571 & 3 \\
\hline \multicolumn{3}{|c|}{ Critical Value Bounds } \\
\hline Significance & I0 Bound & I1 Bound \\
\hline $10 \%$ & 2.72 & 3.77 \\
\hline $5 \%$ & 3.23 & 4.35 \\
\hline $2.5 \%$ & 3.69 & 4.89 \\
\hline $1 \%$ & 4.29 & 5.61 \\
\hline
\end{tabular}

Sumber: data diolah, 2019

Hasil uji kointegrasi berdasarkan pendekatan Bound Test pada tabel 13 diatas menunjukkan nilai F-statistik sebesar 5,596571, yang berarti nilai F-statistik $(5,596571)>$ nilai I0 Bound baik pada tingkat signifikansi 10\%, 5\%, $2,5 \%$ dan $1 \%$. Maka dapat disimpulkan bahwa terdapat kointegrasi pada variabel-variabel dalam 
model yang diuji sehingga adanya keseimbangan jangka pendek menuju jangka panjang pada variabel-variabel tersebut.

\section{Hasil Estimasi Model ARDL}

Model ARDL (Autoregressive Distributed Lag) merupakan model dinamis yang dapat melihat hubungan jangka panjang dan jangka pendek.

\section{Koefisien Jangka Panjang dan Jangka Pendek}

Berdasarkan hasil pengujian kointegrasi Bound Test pada penelitian ini, telah terjadi keseimbangan jangka panjang dalam hubungan faktor-faktor yang mempengaruhi Impor Beras di Indonesia. Hasil hubungan jangka panjang dan jangka pendek berdasarkan model ARDL dapat diestimasi seperti pada tabel berikut:

\section{Tabel 14}

Koefisien Jangka Panjang

\begin{tabular}{|c|r|r|l|}
\hline \multicolumn{4}{|c|}{ Long Run Coefficients } \\
\hline Variable & \multicolumn{1}{c|}{ Coefficient } & t-Statistic & Prob. \\
\hline INFLASI & -235893.234043 & -1.149277 & 0.2728 \\
\hline $\begin{array}{c}\text { NILAI_TUKAR_ } \\
\text { RUPIAH }\end{array}$ & -2060.709369 & -3.416534 & 0.0051 \\
\hline HARGA_ECERAN & 11.844196 & 3.545274 & 0.0040 \\
\hline C & 17760150.733045 & 3.352205 & 0.0058 \\
\hline
\end{tabular}

Sumber: data diolah, 2019

\section{Tabel 15}

Koefisien Jangka Pendek

\begin{tabular}{|c|r|r|r|}
\hline Variable & Coefficient & t-Statistic & Prob.* \\
\hline IMPOR_BERAS(-1) & -0.226190 & -0.907953 & 0.3818 \\
\hline INFLASI & -289250.0 & -1.176916 & 0.2620 \\
\hline NILAI_TUKAR_RUPIAH & -1200.242 & -1.252236 & 0.2343 \\
\hline $\begin{array}{c}\text { NILAI_TUKAR_RUPIAH(- } \\
\text { 1) }\end{array}$ & -1326.579 & -1.251862 & 0.2345 \\
\hline HARGA_ECERAN & 14.52324 & 2.883046 & 0.0138 \\
\hline C & 21777323 & 3.155014 & 0.0083 \\
\hline
\end{tabular}

Sumber: data diolah, 2019

\section{1) Hubungan Inflasi terhadap Impor Beras}

Pada tabel 4.12 dan tabel 4.13 hasil yang didapat yaitu pada jangka panjang dan jangka pendek variabel Inflasi tidak berpengaruh signifikan dan negatif terhadap Impor Beras, dimana nilai probabiliti jangka panjang sebesar 0,2728 dan nilai probabiliti jangka pendek sebesar
0,2620 lebih besar dari taraf nyata $5 \%(0,05)$. Hal ini sejalan dengan penelitian yang dilakukan oleh Saputra \& Swara (2014), bahwa inflasi tidak berpengaruh dan tidak signifikan terhadap impor gula di Indonesia. hal ini juga sejalan dengan penelitian yang dilakukan oleh Wati \& Sudiana (2013), menyatakan bahwa inflasi tidak berpengaruh terhadap Impor Sayuran Indonesia, artinya naik turunnya Inflasi tidak mempengaruhi Impor. Inflasi dikatakan tidak berpengaruh terhadap impor dikarenakan importir tidak memperhatikan presentase tingkat inflasi, jadi berapapun tingkat inflasi tidak akan mempengaruhi daya beli masyarakat Indonesia. Karena Beras merupakan makanan pokok atau kebutuhan pokok bagi masyarakat Indonesia, tidak terpengaruh dengan naik turunnya harga beras dipasar masyarakat tetap akan membeli karena masyarakat Indonesia membutuhkan beras untuk dikonsumsi sebagai makanan pokok. Akan tetapi kenapa pemerintah masih mengimpor beras dari luar negeri walaupun naik turunnya harga tidak mempengaruhi daya beli masyarakat. Hal ini disebabkan stok beras yang ada di dalam negeri belum bisa memenuhi konsumsi serta produksi beras lokal yang menjadi stok pemerintah terbatas, jika barang terbatas maka harga tidak bisa dikendalikan maka pemerintah menerbitkan izin untuk mengimpor beras. Kebijakan pemerintah sangat dibutuhkan dimana pemerintah seharusnya memberi perhatian khusus pada produksi beras, yaitu dengan memperhatikan keadaan sarana dan prasarana pertanian seperti penyuluhan tentang teknologi, pengadaan pupuk dan bibit dengan harga terjangkau, membuat irigasi dan memperbaiki jalan.

2) Hubungan Nilai Tukar Rupiah terhadap Impor Beras

Hasil analisis menunjukkan bahwa variabel Nilai Tukar Rupiah pada jangka panjang memiliki pengaruh signifikan dan negatif terhadap Impor Beras, dimana nilai probabiliti sebesar 0,0051 lebih besar dari taraf nyata $5 \%(0,05)$ dengan koefisien sebesar $-2060,70$. Artinya jika terjadi peningkatan Nilai Tukar Rupiah sebesar satu rupiah, maka akan menurunkan Impor Beras sebesar 2060,70 rupiah. Hasil analisis tersebut sesuai dengan penelitian terdahulu yang dilakukan 
oleh Sari (2014), menyatakan bahwa hasil yang didapatkan adalah variabel kurs rupiah berpengaruh negatif terhadap volume impor beras Indonesia, dimana apabila menguatnya Nilai Tukar Rupiah terhadap US\$ maka akan membuat volume Impor beras Indonesia menurun. Artinya, menguat nilai tukar rupiah yaitu apabila sebelumnya 1 dollar $=$ Rp 10.000 menjadi 1 dollar $=\operatorname{Rp~5.000,~}$ dengan menguatnya kurs Rupiah maka masyarakat akan membeli barang-barang dari luar negeri sebanyak-banyaknya.

3) Hubungan Harga Eceran terhadap Impor Beras

Berdasarkan hasil analisis menunjukkan bahwa Harga Eceran pada jangka panjang memiliki pengaruh signifikan dan positif terhadap Impor beras, hal ini dapat dilihat pada nilai probabiliti sebesar 0,0040 lebih besar dari taraf 5\% $(0,05)$ dengan koefisien jangka panjang sebesar 11,844196. Artinya jika terjadi kenaikan sebesar satu rupiah, maka akan menyebabkan terjadinya kenaikan Impor Beras sebesar 11,84 rupiah. Hasil analisis pada jangka pendek menunjukkan bahwa Harga Eceran memiliki pengaruh signifikan dan positif terhadap Impor Beras dengan nilai probabiliti sebesar 0,0138 lebeih besar dari taraf $5 \%(0,05)$ dengan koefisien jangka pendek sebesar 14,52324. Artinya jika terjadi kenaikan sebesar satu Rupiah, maka akan menyebabkan terjadinya kenaikan Impor Beras sebesar 14,52 rupiah.

Hal ini sejalan dengan penelitian yang dilakukan oleh Prinadi et al., (2016), menunjukkan hasil bahwa harga berpengaruh secara signifikan terhadap volume Impor Beras Indonesia, dengan kata lain meningkatnya harga membuat impor ikut mengalami peningkatan. Secara pendekatan substitusi, apabila harga beras dalam negeri meningkat maka permintaan terhadap beras luar negeri meningkat dengan asumsi harga beras luar negeri tidak terjadi peningkatan. Karena beras merupakan kebutuhan pokok walaupun harga naik beras akan tetap dibeli. Harga naik karena stok beras dan produksi beras dalam negeri tidak mencukupi kebutuhan dalam negeri makanya pemerintah melakukan Impor Beras dengan tujuan memperkuat cadangan beras nasional dan tidak terjadi gejolak harga.

\section{KESIMPULAN}

Berdasarkan hasil analisis dan pembahasan yang dipaparkan sebelumnya, penulis memperoleh kesimpulan yang dapat diambil dari penelitian mengenai faktor-faktor yang mempengaruhi Impor Beras Indonesia adalah sebagai berikut:

1. Berdasarkan hasil estimasi diketahui dan dijelaskan bahwa secara simultan atau bersama-sama Inflasi, Nilai Tukar Rupiah dan Harga Eceran berpengaruh positif dan signifikan terhadap Impor Beras Indonesia. dengan diperoleh nilai F-statistik sebesar 9,611139, berarti faktor-faktor yang menentukan Impor Beras salah satunya merupakan Inflasi, Nilai Tukar Rupiah dan Harga Eceran.

2. Berdasarkan hasil estimasi dijelaskan bahwa secara parsial variabel Inflasi berpengaruh negatif dan signifikan terhadap Impor Beras Indonesia. Dengan diperoleh nilai t-statistik sebesar -2,431964 dan nilai probabiliti sebesar 0,0280 pada tingkat signifikansi sebesar $5 \%$ $(0,05)$, maka terdapat hubungan yang signifikan antara Inflasi dengan Impor Beras.

3. Berdasarkan hasil estimasi dijelaskan bahwa secara parsial variabel Nilai Tukar Rupiah tidak berpengaruh dan negatif terhadap Impor Beras Indonesia. Dengan diperoleh nilai tstatistik sebesar $-2,017346$ dan nilai probabiliti sebesar 0,0619 pada tingkat signifikansi sebesar 5\% $(0,05)$, maka tidak ditemui hubungan yang signifikan antara Nilai Tukar Rupiah dengan Impor Beras.

4. Berdasarkan hasil estimasi dijelaskan bahwa secara parsial variabel Harga Eceran berpengaruh signifkan dan positif terhadap Impor Beras Indonesia. Dengan diperoleh nilai t-statistik sebesar 3,434727 dan nilai probabiliti sebesar 0,0037 pada tingkat signifikansi sebesar 5\% (0,05), maka ditemui hubungan yang signifikan antara Harga Eceran dengan Impor Beras.

5. Pada jangka pendek dan jangka panjang variabel Inflasi tidak berpengaruh signifikan dan negatif terhadap Impor Beras Indonesia. dengan diperoleh nilai probabiliti jangka panjang sebesar 0,2728 dan probabiliti jangka pendek sebesar 0,2620 dengan taraf nyata 5\%, maka tidak ada hubungan jangka panjang dan 
jangka pendek antara variabel Inflasi dengan Impor Beras Indonesia.

6. Pada jangka panjang variabel Nilai Tukar Rupiah memiiki hubungan negatif dan signifikan terhadap Impor Beras Indonesia. Dengan diperoleh nilai probabiliti 0,0051 dengan taraf nyata 5\%, maka terdapat hubungan jangka panjang atara variabel Nilai Tukar Rupiah dengan Impor Beras.

7. Pada jangka pendek dan jangka panjang variabel Harga Eceran berpengaruh signifikan dan Positif terhadap Impor Beras Indonesia dengan diperoleh nilai probabiliti jangka panjang sebesar 0,0040 dan probabiliti jangka pendek sebesar 0,0138 dengan taraf nyata 5\%, maka terdapat hubungan jangka panjang dan jangka pendek antara variabel Harga Eceran dengan Impor Beras Indonesia.

\section{Implikasi Terhadap Kebijakan Pemerintah}

Berdasarkan hasil analisis dan penelitian, maka saran yang dapat diberikan oleh penulis terhadap kebijakan pemerintah adalah sebagai berikut:

1. Bagi pemerintah pusat diharapkan dapat meningkatkan perhatian dalam kebijakan pemberasan di Indonesia, khususnya pada produksi beras. Perlu adanya upaya lebih keras lagi agar produksi beras dapat meningkat melebihi dari kebutuhan nasional maupun juga kesejahteraan petani sehingga SDM yang bekerja di bidang pertanian tidak alih profesi bahkan menjual lahan miliknya untuk kepentingan non-pertanian.

2. Bagi pemerintah pusat diharapkan juga memperhatikan keadaan sarana dan prasaran pertanian dan hal-hal yang berkaitan seperti; irigasi, pupuk, bibit, distribusi, pelabuhan, jalan dan lain sebagainya. Gunanya agar mencapai kelancaran dunia pemberasan di Indonesia dari segi patani hingga segi konsumen. Apabila terjadi maka dapat diharapkan kualitas dan harga beras Indonesia di pasar lokal maupun pasar Internasional.

3. Bagi pemerintah pusat agar bersama-sama dengan pemerintah daerah untuk mengawasi proses dalam dunia pemberasan dengan baik.
Agar menghindari terjadinya kecurangan didunia pemberasan. Selain itu memperbaiki celah-celah hukum dalam dunia pemberasan di Indonesia, agar tidak ada pihak-pihak yang memanfaatkan celah hukum sebagai sarana memperoleh keuntungan yang berlebihan namun merugikan banyak pihak.

4. Bagi pemerintah daerah baik tingkat provinsi maupun kabupaten dan kota untuk terus mendukung upaya pemerintah dalam memperbaiki dunia pemberasan di Indonesia. dengan melakukan kebijakan daerah (khususnya bidang pertanian) sejalan dengan kebijakan pemerintah pusat.

5. Bagi pemerintah daerah agar memberikan intensif khusus bagi petani dan pengusaha di bidang pertanian agar mempercepat pengembangan usaha di bidang pertanian seperti; pengawasan pengadaan pupuk dan bibit, pengadaan penyuluhan tentang teknologi, upaya penanggulangan dan pencegahan bencana alam bagi pertanian.

\section{KEPUSTAKAAN}

Asmanto, Priadi dan Sekar Suryandari. (2008). Cadangan Devisa, Financial Deepening Dan Stabilisasi Nilai Tukar Riil Rupiah Akibat Gejolak Nilai Tukar Perdagangan.

Brianto, D. (2015). Pengaruh Produksi Beras, Impor Beras, Tingkat Konsumsi Beras Terhadap Harga Beras Di Indonesia Tahun 2008-2013 (Studi Kasus 32 Provinsi).

Badan Pusat Statistik (BPS). (2018). Statistik Indonesia 2000-2018. Jakarta

Bank Indonesia. (2018). Inflasi. Jakarta

Bank Indonesia. (2018). Nilai Tukar Rupiah. Jakarta

Chen, C. (2012). The Threshold Effects of RMB Exchange Rate Fluctuations on Imports and Exports.

Christianto, E. (2013). Faktor Yang Memengaruhi Volume Impor Beras Di Indonesia. 
Faisol, N. F. (2016). Pengaruh Pertumbuhan Produk Domestik Bruto (Pdb), Laju Inflasi Dan Nilai Tukar Rupaih Terhadap Nilai Impor Indonesia.

Gujarati, Damodar. (2003). Ekonometrika Dasar. Alih Bahasa Sumarno Zain. Erlangga. Jakarta.

Hasyim, A. I. (2016). Ekonomi Makro. Edisi Pertama. Jakarta. PT Fajar Interpratama Mandiri.

https://www.kamusbesar.com/harga-eceran.

Kamus Besar. (2019). Harga Eceran (Diakses pada 08 Maret 2019)

https://id.wikipedia.org/wiki/impor. Wikipedia. (2018). Impor (diakses pada 17 Desember 2018)

https://id.wikipedia.org/wiki/Eceran. Wikipedia. (2019). Eceran (Diakses pada 08 Maret 2019)

Mukhdar, M. (2014). Analisis Faktor-Faktor Yang Mempengaruhi Impor Beras Di Indonesia.

Namira, Y., Nuhung, I. A., \& Najamuddin, M. (2016). Analisis Faktor-Faktor Yang Mempengaruhi Impor Beras Di Indonesia.

Oluwarotimi Odeh, Hanawa, and Hikaru. (2003). The Impacts of Market Power and Exchange Rates on Prices of European Union Soybean Imports.

Paul R Krugman dan Maurice Obstfeld. (2000). Ekonomi Internasional Teori dan Kebijaksanaan. Jakarta. Rajawali Press.

Pesaran dan Shin. (1997). Working With Microfit 4.0 Interactive Econometric Analiysis.

Pakpahan, A. R. S. (2012). Analisis Faktor-Faktor Yang Mempengaruhi Impor Daging Sapi Di Indonesia.

Prinadi, R., Yulianto, E., \& Mawardi, M. K. (2016). Pengaruh Nilai Tukar Rupiah, Harga Beras Internasional dan Produksi Beras Dalam Negeri Terhadap Volume Impor Beras Indonesia ( Studi Impor Beras Indonesia Tahun 2002-2013).

Rachmanti, A., Riyadi, \& Suharmanto. (2016). Pengaruh Inflasi Dan Nilai Tukar Rupiah Terhadap Impor Kedelai Di Jawa Tengah
(Periode 2001-2013).

Saputra, I. K. E., \& Swara, I. W. Y. (2014). Pengaruh Produksi, Konsumsi, Harga Eceran, Inflasi Dan Kurs Dollar As Terhadap Impor Gula Indonesia.

Sari, R. K. (2014). Analisis Impor Beras Di Indonesia.

Setiadi, I. O. (2013). Analisis Faktor-Faktor Yang Mempengaruhi Permintaan Uang Di Indonesia Tahun 1999: Q1 - 2010: Q4 Dengan Pendekatan Error Corection Models (ECM).

Syamsuddin, N., Hamzah, P. D. A., \& Dr. Muhammad Nasir, M.Si, M. (2013). Analisis Faktor-Faktor Yang Mempengaruhi Impor Beras Di Indonesia.

Sukirno, Sadono. (2002). Pengantar Teori Mikro . Edisi Ketiga. Jakarta. PT Raja Grafindo Persada.

Wati, A. A. I. D. C., \& Sudiana, I. K. (2013). Pengaruh Produk Domestik Bruto (Pdb), Kurs Dollar Amerika Serikat Dan Inflasi Terhadap Impor Sayuran Indonesia Kurun Waktu 1994-2013. 1-21.

Zakaria. J. (2009). Pengantar Teori Ekonomi Makro. Edisi Pertama. Jakarta. Gaung Persada (GP Press). 